\title{
DRIVERS OF TEMPERATE WOODLAND CONDITION THROUGH TIME IN AN AGRICULTURAL LANDSCAPE
}

Chloe F. Sato ${ }^{\text {a* }}$, Daniel Florance ${ }^{\mathrm{a}}$, and David B. Lindenmayer ${ }^{\mathrm{a}}$

${ }^{a}$ Fenner School of Environment and Society,

The Australian National University,

141 Linnaeus Way

Acton, ACT, 2601

Australia

Email: chloe.sato@anu.edu.au daniel.florance@anu.edu.au

david.lindenmayer@anu.edu.au

* Corresponding author

Running Title:

DRIVERS OF VEGETATION PATTERNS IN AN AGRICULTURAL LANDSCAPE

Word Count: Abstract: 250 (max 250 words)

Main Text: 4250 (max 6000 words)

Acknowledgements: 109

References: 1864

Table and Figure Legends: 259

Number of Tables and Figures: 5

Number of References: 64

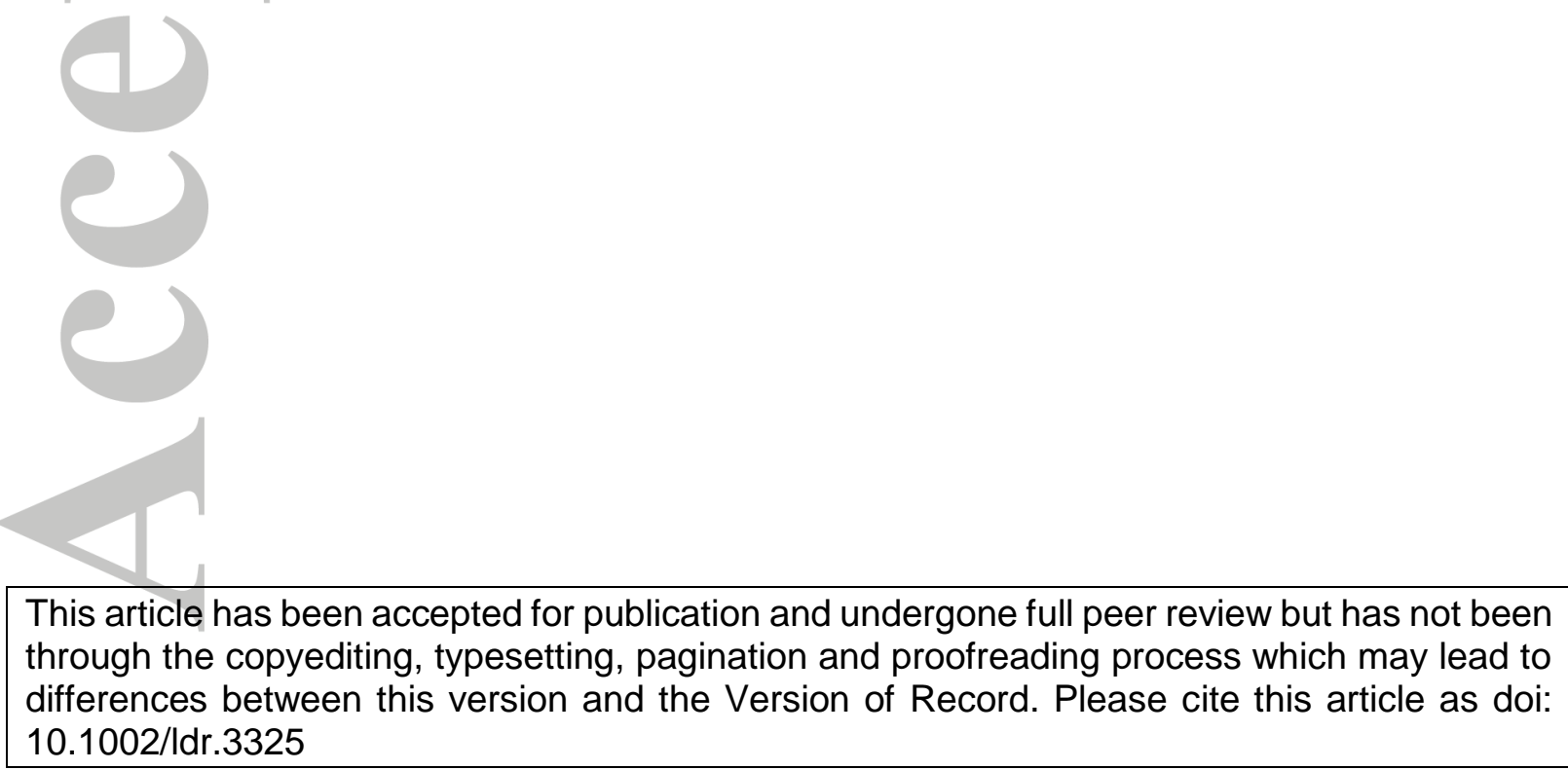




\section{ABSTRACT}

Conversion of natural woodlands to grazing pastures is a major driver of biodiversity loss. In response to this threat, regenerative management approaches have been proposed to balance agriculture with biodiversity conservation. Yet, rigorous experiments investigating the effectiveness of such approaches are rare. We used time-series data from a broad-scale experiment in south-eastern Australian woodlands to explore the effects of agricultural practices and environmental factors on regeneration, bare ground, and native and exotic cover and richness. Our study included historical fertilization, three past grazing regimes (continuous, short-conversion rotational, long-conversion rotational), two present-day grazing measures (grazing duration, stocking rate), and three environmental covariates (natural soil fertility, native woody cover, rainfall). We found fertilizer application was associated with altered trajectories of native overstorey cover, native plant richness, exotic cover and bare ground. Changes in woodland condition also was associated with a combination of presentday grazing and environmental drivers. Natural regeneration, native plant richness, and native herb cover were negatively associated with increased grazing intensity. Conversely, increased landscape-scale native woody cover and local-scale natural soil fertility were associated with increases in native overstorey cover and native plant richness; and decreases in exotic cover and bare ground.

Our results indicate that land-use history, present grazing intensity and landscape context alter woodland ecosystem responses to intervention. This may explain why some conservation actions fail to meet objectives. Our results indicate that the effectiveness of conservation actions can be improved by considering the combined influence of past and present agricultural management and landscape context on woodland condition.

KEYWORDS: agro-ecosystem; Australia; fertilizer; landscape context; livestock grazing; plant richness; temperate woodland; vegetation cover 


\section{INTRODUCTION}

Land-use change is one of the greatest global threats to biodiversity (Haddad et al., 2015). Approximately $55 \%$ of ice-free terrestrial habitats worldwide have been modified, with agriculture being a major driver of land-use change (Ellis et al., 2010). Pressure to expand and intensify agricultural land use to meet global food demand (Godfray et al., 2010) poses a serious threat to biodiversity (Loos et al., 2014) through habitat loss (CBD, 2010; McIntyre, 2011) and modification (van Klink et al., 2015b), changes to soils (e.g. elevation of nutrients and increased soil compaction, Dorrough et al., 2006; Close et al., 2008; van Klink et al., 2015a), and direct animal or plant mortalities caused by trampling (van Klink et al., 2015b).

In ecosystems modified for (i.e. through land clearing and/or fertilizer use) or affected by livestock grazing, continuously grazed systems have negatively affected natural regeneration capacity (Sato et al., 2016) and reptile patch colonization probabilities (Kay et al.,2017), but have positively influenced diversity of obligate grassland birds (Ranellucci et al., 2012). Rotational grazing systems (i.e. systems where paddocks undergo alternate periods of grazing and rest; Dorrough et al., 2012) have negatively affected grasshopper abundance (Onsager, 2000) and bird richness (Dorrough et al., 2012), but positively influenced flowervisiting invertebrate richness and abundance (Ravetto Enri et al., 2017), availability of bird nesting habitat (Carroll et al., 2007) and plant basal area (Teague et al., 2004). Inconsistent effects of different grazing regimes on biodiversity may be observed as other specific factors, like grazing intensity (e.g. timing, duration and stocking rate; Dorrough et al., 2012; Eldridge et al., 2016; Kay et al., 2017) or fertilizer application (Dorrough et al., 2006; Dorrough et al., 2012), may be stronger drivers of biodiversity patterns than broad types of grazing regime (i.e. rotational versus continuous grazing). 
In Australia, restoration programs in agricultural landscapes have shifted from maximising agricultural production towards balancing agricultural productivity with biodiversity conservation (DEWHA, 2009; Duncan \& Dorrough, 2009). These programs can play an important role in the preservation of threatened ecosystems occurring across agricultural lands (Spooner \& Briggs, 2008), including temperate grassy woodlands. Temperate grassy woodlands presently cover approximately 415000 hectares of eastern Australia (TSSC, 2006) but have been extensively affected by land conversion for agriculture. Over $90 \%$ of Australian temperate grassy woodlands have been cleared since European settlement (TSSC, 2006) and remaining remnants are often degraded (Yates \& Hobbs, 1997). Moreover, remnants in good condition face the continued threat of degradation from agriculture (McIntyre, 2012) as they occur predominantly on private lands (Zammit et al., 2010). Improving understanding of long-term influences of grazing and fertilizer application on key ecosystem features in temperate grassy woodlands will help support the recovery of temperate grassy woodlands, prevent their further degradation, and strike a balance between agricultural production and biodiversity conservation (Lindenmayer et al., 2010b).

Despite the importance of understanding long-term grazing and fertilization effects on biodiversity, rigorous experimental studies investigating this subject are rare (Lagendijk et al., 2017). To address this knowledge gap, we established a broad-scale, long-term experiment associated with an agri-environment scheme in temperate grassy woodland to explore the effects of different grazing regimes (continuous and rotational grazing; Table 1) and historical fertilizer application (Table 1) on temporal patterns of woodland condition indicators (including native and exotic plant richness and cover, bare ground cover, overstorey cover and presence of tree regeneration). For grazing, the in situ past grazing regime (continuous, short-conversion rotational, or long-conversion rotational) was 
maintained at approximately half of our sites and a new grazing regime (reduced duration of grazing at a site and/or reduced stocking rate at a site) was implemented at remaining sites in our study. Our study also included additional land management covariates (grazing duration and stocking rate; see Table 1 for definitions) and environmental covariates (rainfall, natural soil fertility, landscape-scale native woody cover; see Table 1 for definitions) to determine the relationship of these factors with woodland condition indicators compared with past land management practices.

At the outset of this study, we postulated that, over time, agricultural practices such as grazing and historical fertilizer application would be associated with increased bare ground and increased proportion of exotic plant species cover, as well as increased exotic plant species richness. However, consistent with previous research, we expected that any increase in bare ground, exotic cover and exotic plant richness would be most pronounced in areas with a continuous grazing history (Leonard \& Kirkpatrick, 2004; Eldridge et al., 2011) or where fertilizer had been previously applied (Dorrough et al., 2011). We also expected that areas with higher stocking rates would be associated with higher cover and richness of exotic plant species (Close et al., 2008; Dorrough et al., 2011), declining through time where overgrazing occurs for extended periods. In contrast, we postulated that condition indicators characteristic of increased woodland quality (e.g. native plant species richness, cover of native herbs, tree regeneration) would exhibit negative associations with agricultural practices. However, we expected these responses would be less pronounced in areas with limited or no history of fertilizer application (Dorrough \& Moxham, 2005; Wassen et al., 2005; Close et al., 2008; Fischer et al., 2009; Dorrough et al., 2012), or in rotational grazing systems (Dorrough \& Moxham, 2005; Chillo et al., 2015) - particularly where pastures are rested during peak flowering and seed-set periods (Leonard \& Kirkpatrick, 2004). We also expected that, in areas with decreased grazing intensity (i.e. duration of grazing events and/or 
stocking rates), reduced rates of decline in tree regeneration (Fischer et al., 2009), tree cover (Fischer et al., 2010) and native plant richness (Dorrough et al., 2012) would be observed..

Finally, we postulated that environmental variables would mediate the effects of grazing on woodland condition indicators. We expected that rainfall would be associated with changes in patterns of native plant richness (Gibbons et al., 2008), increases in the cover of exotic plants (Prevéy \& Seastedt, 2014) and increased rates of natural tree regeneration (Clarke, 2000). In addition, we expected that increased natural soil fertility would be associated with reduced levels of natural tree regeneration (Sato et al., 2016), and increased native woody cover in the surrounding landscape would be associated with increases in tree regeneration (Manning et al., 2006; Fischer et al., 2009; Sato et al., 2016), native plant richness and native groundcover through time (Manning et al., 2006). We further expected that negative effects of grazing on woodland condition indicators would be lessened in areas supporting greater landscape-scale native woody cover, consistent with the findings of Sato $e t$ al. (2016).

\section{METHODS}

\section{Study Region and Study Design}

In southern New South Wales, Australia, we established 97 sites between 2010 and 2011 on 29 farms involved in an agri-environment scheme over an area of approximately $100 \mathrm{~km}$ east to west, and $150 \mathrm{~km}$ north to south (Fig. 1). Cropping and livestock grazing by sheep (Ovis aries) and cattle (Bos taurus) are the dominant land use practices occurring across farms in the study region (Yates \& Hobbs, 1997; Barton et al., 2016). However, all farms selected for this study supported woodland remnants characterised by a discontinuous (20-50\% cover) overstorey dominated or co-dominated by yellow box (Eucalyptus melliodora A.Cunn. ex Schauer), white box (E. albens Benth.), Blakely's red gum (E. blakelyi Maiden) or grey box 
(E. microcarpa Maiden) (TSSC, 2006; DEWHA, 2009; DECCW, 2010). The understorey of intact remnants supports a diverse assemblage of tussock grasses, herbs and patchy $(<30 \%)$ shrub cover (TSSC, 2006; DECCW, 2010), but highly degraded remnants are likely to predominantly support an understorey of exotic forage plants (Dear \& Ewing, 2008). We classified in situ past grazing regime of each farm as either continuous (i.e. livestock allowed to graze sites year-round; sensu Barton et al., 2016), long-conversion rotational (i.e. for > 10 years prior to our study, livestock have been rotated through sites, grazing each for a limited duration [median = 4 days]; sensu Barton et al., 2016) or short-conversion rotational (i.e. for $<5$ years prior to our study, livestock have been rotated through sites, but grazing each for a limited duration [median = 12 days]; sensu Barton et al., 2016). On each farm, we established up to four survey sites in eucalypt woodland remnants. The past grazing regime (continuous, short-conversion rotational, long-conversion rotational) was maintained at 41 sites (15 continuous grazing sites, 11 short-conversion rotational grazing sites, 15 long-conversion rotational grazing sites) and a new grazing regime (reduced duration of grazing at a site and/or reduced stocking rate at a site) was implemented at 56 sites in our study in 2011 . We used the three 'past grazing treatment' categories in subsequent statistical analysis to represent pre-2011 grazing management. However, we used grazing frequency, duration and intensity data to represent post-2011 grazing management as this information was collected consistently across farms between 2012 and 2016 from landholder surveys. The grazing frequency, duration and intensity data allowed us to generate two grazing variables for analysis: (1) mean duration of grazing events (days, on average, over a whole year) and (2) mean stocking rate of grazing events (per hectare per day, on average, over a whole year) (sensu Kay et al., 2017) (see Table S2 for this article). Prior to calculating mean stocking rate, we standardised livestock numbers to a 'dry sheep equivalent' (DSE) to account for differential effects of sheep and cattle grazing (following Barton et al., 2016). We also 
interviewed landholders to determine whether previous application of fertilizer on each site in our study had occurred. While fertilizer application did not necessarily occur within woodland remnants in our study, the remnants are embedded in an agricultural matrix where fertilizer application occurred. Under such circumstances, fertilizer may ‘leak' onto nonproduction land (McIntyre, 2010) with subsequent effects on biodiversity (e.g. weed incursions in remnants; McIntyre, 2010).

\section{Field Data Collection}

At each of our 97 sites, we completed vegetation surveys between January and May each year from 2012 to 2016. Following field methods outlined by Sato et al. (2016), we measured percentage cover for ground layer native and exotic plants, bare ground, and overstorey along a $200 \mathrm{~m}$ transect, native and exotic plant richness within a 20 x $20 \mathrm{~m}$ plot centred over the $200 \mathrm{~m}$ transect, and presence of natural eucalypt regeneration within two 50 x $20 \mathrm{~m}$ plots adjacent to the $200 \mathrm{~m}$ transect. For details regarding measured site-level attributes, see Table S1.

For each site, we collected three spatially-derived environmental variables using ArcGIS 10.4.1: natural soil fertility (a local-scale measure of substrate fertility based on underlying lithology), native woody vegetation cover in a $250 \mathrm{~m}$ buffer around the site, and mean annual rainfall. For details regarding environmental variables compiled and software used to compile descriptors, see Table S2.

\section{Statistical Analysis}

Treatment of data

For all 97 sites in our study, we aggregated plot-level data for eucalypt regeneration measures to obtain site-level estimates for each year of observation. We subsequently 
excluded sites where data were not collected in each year of interest (2012 to 2016 inclusive) or were not available regarding the historical application of nutrients or contemporary grazing practices (i.e. paddock level information about grazing duration and/or intensity). In total, we retained data from 75 sites for detailed statistical analysis.

\section{Factors driving temporal patterns of woodland condition indicators}

To investigate the relationship between past grazing and fertilization on the trajectories of woodland condition indicators through time (accounting for grazing intensity and environmental covariates), we fitted a single generalised linear mixed model (GLMM) for each of the seven woodland condition indicators collected at each site. The indicators we included in analyses related to woodland character or condition (from state and transition models for box gum grassy woodlands, see McIntyre \& Lavorel, 2007; Rumpff et al., 2011): $\%$ exotic ground cover, $\%$ native herb cover, $\%$ bare ground cover, $\%$ overstorey cover, presence of natural tree regeneration, ground layer native plant richness and ground layer exotic plant richness.

For each GLMM, we included the woodland condition indicator (e.g. overstorey cover, exotic cover etc.) as the response variable, and 'Year' (categorical factor), as well as 'Site' nested within 'Farm' as random effects to account for temporal and spatial structuring of the data. For models including cover variables as the response, we assumed a quasibinomial distribution with logit-link function. For models including native or exotic plant richness as the response, we assumed a quasi-Poisson distribution with a log-link function. For models including regeneration presence as the response, we assumed a Bernoulli distribution with logit-link function. For each model, we fitted an interaction between Year (continuous variable) and past grazing regime (three levels: continuous, long-conversion rotational, short-conversion rotational), Year and historical fertilization, and the additive 
effects of stocking rate, grazing event duration, rainfall, native woody cover and natural soil fertility as fixed effects. During modelling, we used Wald tests to assess the significance of each predictor variable included in the model. We sequentially removed interactions that were not significant from the relevant model(s) (via backwards stepwise selection) to limit the masking of effects of potentially important variables. We conducted all statistical analyses in GenStat 18.2 (VSN International Ltd).

\section{$\underline{\text { RESULTS }}$}

We found that past land management was not significantly associated with the temporal trajectories of natural regeneration, exotic plant richness or native herb cover (Table 2, Table S3). However, historical fertilizer application was significantly associated with temporal patterns of native overstorey cover $\left(\chi_{1}^{2}=6.29, \mathrm{P}=0.013\right)$, native plant richness $\left(\chi_{1}^{2}\right.$ $=3.92, \mathrm{P}=0.049)$, exotic cover $\left(\chi_{1}^{2}=6.43, \mathrm{P}=0.012\right)$ and bare ground $\left(\chi_{1}^{2}=18.57, \mathrm{P}<\right.$ 0.001; Table 2, Table S3). Through time, both overstorey cover and bare ground exhibited significant increases on sites with previous history of fertilization but remained stable on sites with no previous fertilizer application (Fig. 2). In contrast, native plant richness declined across our study region through time, but observed declines were stronger on sites with a history of fertilization (Fig. 2). Finally, exotic cover exhibited a significant decline through time on sites with previous history of fertilization but an increase on sites with no previous fertilizer application (Fig. 2).

Past grazing regime was not significantly associated with the temporal or spatial patterns of any woodland condition indicator included in this study, and exotic plant species richness was not significantly associated with any of the variables included in our analysis (Table 2, Table S3). 


\section{The relationship between present land management and woodland condition indicators}

Present-day grazing intensity was associated with three woodland condition indicators: natural tree regeneration, native species richness, and native herb cover. A site was significantly less likely to support native tree regeneration as the duration of grazing events increased $\left(\chi_{1}^{2}=5.63, \mathrm{P}=0.018\right.$; Table 2 , Table S3). If the duration of grazing events exceeded one month, significantly fewer sites were predicted to support natural regeneration when compared to sites with no grazing (Fig. 3a). Similarly, native species richness $\left(\chi_{1}^{2}=\right.$ 5.45, $\mathrm{P}=0.023)$ and native herb cover $\left(\chi_{1}^{2}=4.74, \mathrm{P}=0.035\right)$ declined as stocking rates increased (Table 2, Table S3). If mean daily stocking rates of grazing events exceeded 115 DSE per hectare, significantly fewer native plant species were predicted to occur on site when compared to sites with no grazing (Fig. 3b). If mean daily stocking rates of grazing events exceeded 150 DSE per hectare, significantly lower cover of native herbs was predicted on site when compared to sites with no grazing (Fig. 3c).

\section{The relationship between environmental variables and woodland condition indicators}

Native woody cover and natural soil fertility, but not rainfall, were associated with patterns of three woodland condition indicators: native overstorey cover, native plant species richness, exotic cover and bare ground. As native woody cover increased in the landscape surrounding a site, native overstorey cover $\left(\chi_{1}^{2}=9.92, \mathrm{P}=0.003\right)$ and native plant species richness $\left(\chi_{1}^{2}=5.99, \mathrm{P}=0.017\right)$ increased on site, while exotic cover decreased $\left(\chi_{1}^{2}=4.26, \mathrm{P}\right.$ $=0.043 ;$ Table 2, Table S3). As natural soil fertility of a site increased, bare ground decreased $\left(\chi_{1}^{2}=11.29, \mathrm{P}=0.004 ;\right.$ Table 2, Table S3).

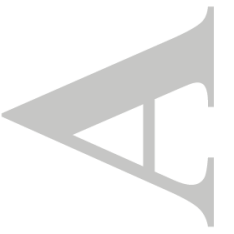




\section{DISCUSSION}

Past and present land management practices in agricultural landscapes, including livestock grazing and fertilization, can have deleterious effects on biodiversity (Hautier et al., 2009; Socher et al., 2013; Etchebarne \& Brazeiro, 2016), often degrading the condition of natural ecosystems (Hautier et al., 2014; Eldridge et al., 2016) and influencing the recovery trajectories of attributes indicative of ecosystem condition (Chillo et al., 2015; Sato et al., 2016). Using time-series data from a broad-scale grazing experiment, we found that historical fertilizer application - but not past grazing regime - was associated with changes in trajectories of four woodland condition indicators (native overstorey cover, native plant richness, exotic cover and bare ground). In addition, spatial patterns of woodland condition indicators were associated with a combination of land management and environmental drivers. Increased stocking rates and grazing duration were associated with declines in woodland condition (i.e. declines in natural tree regeneration, native plant richness and native herb cover). In comparison, increased landscape-scale native woody cover and local-scale natural soil fertility were associated with improved woodland condition (i.e. increased native overstorey and native plant richness, and decreased exotic cover and bare ground). These findings have important implications for the conservation of biodiversity in agricultural landscapes, as well as the design and evaluation of conservation schemes in agro-ecosystems.

\section{Are agricultural production and biodiversity conservation incompatible?}

There is often a conflict between the objectives of maximising agricultural production through livestock grazing and fertilizer application, and in managing landscapes for biodiversity conservation in agro-ecosystems. This is because livestock grazing and fertilizer application often negatively affect biodiversity (Wassen et al., 2005; Dorrough et al., 2011; Eldridge et al., 2016). Our study showed that achieving the dual objectives of agricultural 
production and biodiversity conservation is challenging in agricultural systems because past fertilizer application and current grazing intensity often negatively affect woodland condition. Based on our data, the best biodiversity conservation outcomes will likely be achieved on sites where there is no previous history of fertilizer application, where mean stocking rates for grazing events are < 95 DSE per hectare per day (to maintain > 13 native plant species on site; see Fig. 3), and where grazing events are $<40$ days in duration (to ensure that at least $50 \%$ sites in an area support natural regeneration; see Fig. 3). If these grazing intensity thresholds are exceeded, negative effects on woodland condition may occur (e.g. fewer native plant species occur on site and fewer woodland patches supporting natural regeneration). In addition, if sites have a previous history of fertilizer application, the capacity of the ground layer to support and recruit native plant species may be reduced, potentially impeding positive conservation outcomes despite the implementation of conservation-related management actions (e.g. reductions in grazing intensity and/or biodiversity-sensitive timing of grazing). However, given that recovery from defoliation is an important factor of survival for many plants (e.g. grasses; Del-Val and Crawley 2005), we recommend that further focused research on the influence of timing and duration of recovery periods between grazing events on long-term woodland floristic condition be undertaken. We further suggest that this research be undertaken in areas with and without previous fertiliser application (where possible) to more accurately assess the success of conservation-related grazing actions, and to provide greater guidance on tailoring grazing strategies to improve conservation outcomes. Interestingly, in areas where fertilizer had historically been applied, we observed a decrease in exotic cover and an increase in bare ground through time, which is not consistent with previous research in woodlands (e.g. Close et al., 2008; Dorrough et al., 2011). The decrease in exotic cover may be due, in part, to increased intensity of weed control actions occurring on previously fertilized sites as part of landholder contractual obligations (see 
DEWHA, 2009). Increased weed control action may also explain the increase in bare ground observed at sites with a history of fertilization given that, with the decrease in exotic cover, a concomitant increase in native plant richness or cover was not observed. However, the patterns in exotic cover and bare ground cannot be definitively attributed to altered land management actions or intensity without further investigation.

Importantly, to enhance woodland condition in agricultural landscapes, protecting and increasing native woody cover in the landscape surrounding a farm is critical. Native woody cover in the surrounding landscape was positively associated with indicators characteristic of improved woodland quality such as increased native overstorey cover and native plant richness (substantiating predictions from the outset of our study). Increased native woody cover also was associated with decreases in exotic cover; an indicator typically associated with poorer woodland quality. Thus, it is vital that remnant tree cover be protected across landscapes where livestock grazing and other agricultural practices occur, to maintain woodland biodiversity and its associated ecosystem services.

To ensure that agri-environment schemes are effective, landscape-scale protection of native woody cover will be critical to improving conservation outcomes and justifying investments in such schemes (e.g. \$55.9 million AUD budget for 2013-2017 for the Environmental Stewardship Program in Australia; Australian Government, 2014). Landscape-scale woody vegetation cover has been considered in the design of some conservation programs. For example, 'landscape value' (i.e. percent vegetated cover in 1000 ha and 10000 ha buffers) was a metric used in initial Environmental Stewardship Program site assessments (Whitten et al., 2009). Similarly, availability of connected or 'stepping stone' woody vegetation adjacent to conservation patches formed part of Multiple Ecological Community site assessments (Whitten et al., 2010). However, there are currently no explicit contractual obligations for land managers involved in conservation programs to protect native 
woody vegetation beyond the bounds of remnants targeted for conservation purposes (DEWHA, 2009; Natural England, 2012). In Australia, this issue is compounded by relaxed protection measures in native vegetation legislation that has led to accelerated vegetation clearing (DSITI, 2017). This lack of landscape-scale woody cover protection may, in part, explain why some agri-environment schemes do not achieve conservation objectives - given that structure and management of surrounding landscape influences agri-environment scheme effectiveness (Batáry et al., 2015). Conversely, by incorporating landscape-scale native woody cover protection into strategic frameworks, policies, and contractual agreements, conservation benefits of agri-environment restoration actions may be enhanced.

Based on our results, we argue that short- and long-term benchmarks and objectives for restoration require careful calibration - or recalibration for agri-environment schemes currently underway. Benchmarks for conservation schemes should reflect how landscapescale native woody cover, local-scale natural soil fertility, and historical fertilizer application alter the restoration potential of woodlands. Careful benchmark development (or recalibration) becomes particularly important in situations where contractual obligations to meet benchmarks in set timeframes may disadvantage landholders in lower quality landscapes (e.g. farms in landscapes with lower landscape-scale native woody cover or low local-scale natural soil fertility may not be able to achieve identified benchmarks).

\section{The future for temperate woodlands in Australian agricultural systems}

Australia has suffered extensive loss of its temperate woodland ecosystems since European settlement (TSSC, 2006), and continues to lose wooded ecosystems to agricultural development. In 2016, 367350 hectares of woody vegetation were cleared for grazing pastures in Queensland alone (DSITI, 2017). Ameliorative actions have been undertaken to offset these losses (e.g. 20 Million Trees Program; Australian Government, 2015) and to 
maintain or improve remaining woodlands (e.g. Environmental Stewardship Program, Lindenmayer et al., 2012). Yet, in much of Australia's temperate woodlands, remnant woodland extent is declining faster than it can be replanted, and remaining woodlands continue to degrade. At a minimum, an understanding of the reasons for continued declines in woodland condition indicators (and consequently continued declines in woodland condition) in areas targeted for conservation is urgently needed. Ongoing investment in long-term monitoring and research can clarify why these systems continue to degrade and whether management is effective (Lindenmayer et al., 2010a). Long-term monitoring also can disentangle whether land-use legacy effects (arising from vegetation recovery lags; Pierik et al., 2011), or ecosystem collapse (i.e. widespread and potentially irreversible changes in ecosystem conditions that alter the identity of the ecosystem; see Lindenmayer \& Sato, 2018) is the cause of ongoing declines. Under a land-use legacy effect scenario versus an ecosystem collapse scenario, 'current' management would have drastically different effects. An ecosystem exhibiting a land-use legacy effect would be expected to respond (potentially over long time periods; Bullock et al., 2011), while an ecosystem undergoing collapse likely will not (Biggs et al., 2009). If long-term monitoring revealed that the ecosystem is collapsing (Sato \& Lindenmayer, 2017), decisions could then be made regarding how - and whether - to proceed with restoration actions, given that collapse is difficult and expensive to reverse (Biggs et al., 2009).

\section{CONCLUSIONS}

Conservation strategies in our study (i.e. agri-environment schemes that promote biodiversity-sensitive timing of grazing events through rotational grazing) are not resulting in significant improvements in woodland condition at this point in time. This lack of improvement is due - in part - to past and present agricultural practices and broader 
landscape factors influencing the effectiveness of interventions. We argue the importance of considering the relationship between land-use history, present grazing intensity and landscape context - particularly natural soil fertility and native woody cover - and restoration potential when targeting conservation investments and evaluating the success of management interventions. Our findings suggest that no (or limited) fertilizer application, and low intensity and duration of grazing events, are generally beneficial for maintaining woodland condition. That said, farms with different land-use histories, current grazing management and landscape contexts will have different propensities to respond to intervention, different timescales in which vegetation will show responses to intervention, and different capacities to return to baseline conditions. These differences will affect the perceived and actual success of management interventions in agro-ecosystems.

\section{ACKNOWLEDGEMENTS}

This research was supported, in part, by an Australian Research Council (ARC) Linkage Project (Grant number: LP100100467), an ARC Laureate Fellowship (Grant number: FL120100108) awarded to David Lindenmayer, and in its initial phases by the National Environmental Research Program (NERP) and the Australian Government Environmental Stewardship Programme. We thank Geoffrey Kay, David Blair, Mason Crane, Lachie McBurney, Damian Michael, Thea O’Loughlin, Sachiko Okada, Mitch Francis, Scott Lucas, Mal Miles, Dale Nimmo, Steve Rowe, Mark Shortis, Greg Slade, David Trengrove and Christian Wythes for their assistance in collecting field data. We also thank Ben Scheele and two anonymous referees for providing valuable feedback on earlier versions of the manuscript. 


\section{REFERENCES}

Australian Government 2014. Budget review 2014-2015. Retrieved from

http://www.aph.gov.au/About_Parliament/Parliamentary_Departments/Parliamentary_Librar y/pubs/rp/BudgetReview201415

Australian Government 2015. Environment and communications references committee:

National landcare program. Retrieved from

https://www.aph.gov.au/Parliamentary_Business/Committees/Senate/Environment_and_Com munications/landcare/Report

Barton, P.S., Sato, C.F., Kay, G.M., Florance, D., Lindenmayer, D.B. 2016. Effects of environmental variation and livestock grazing on ant community structure in temperate eucalypt woodlands. Insect Conservation and Diversity 9: 124-134.

https://doi.org/10.1111/icad.12151

Batáry, P., Dicks, L., Kleijn, D., Sutherland, W. 2015. The role of agri-environment schemes in conservation and environmental management. Conservation Biology 29: 10061016. https://doi.org/10.1111/cobi.12536

Biggs, R., Carpenter, S.R., Brock, W.A. 2009. Turning back from the brink: Detecting an impending regime shift in time to avert it. Proceedings of the National Academy of Sciences 106: 826-831. https://doi.org/10.1073/pnas.0811729106

Bullock, J.M., Aronson, J., Newton, A.C., Pywell, R.F., Rey-Benayas, J.M. 2011. Restoration of ecosystem services and biodiversity: Conflicts and opportunities. Trends in Ecology \& Evolution 26: 541-549. https://doi.org/10.1016/j.tree.2011.06.011

Carroll, L.C., Arnold, T.W., Beam, J.A. 2007. Effects of rotational grazing on nesting ducks in California. The Journal of Wildlife Management 71: 902-905.

https://doi.org/10.2193/2005-564 
CBD [Secretariat of the Convention on Biological Diversity]. 2010. Global biodiversity outlook 3. Retrieved from http://www.cbd.int/gbo3/

Chillo, V., Ojeda, R.A., Anand, M., Reynolds, J.F. 2015. A novel approach to assess livestock management effects on biodiversity of drylands. Ecological Indicators 50: 69-78. https://doi.org/10.1016/j.ecolind.2014.10.009

Clarke, P.J. 2000. Plant population processes in temperate woodlands of eastern australia - premises for management. In R.J. Hobbs, C. Yates (Eds.), Temperate eucalypt woodlands in Australia: Biology, conservation, management and restoration (pp. 248-270). Chipping Norton: Surrey Beatty \& Sons, pp. 248-270.

Close, D.C., Davidson, N.J., Watson, T. 2008. Health of remnant woodlands in fragments under distinct grazing regimes. Biological Conservation 141: 2395-2402. https://doi.org/10.1016/j.biocon.2008.07.006

Dear, B.S., Ewing, M.A. 2008. The search for new pasture plants to achieve more sustainable production systems in southern Australia. Australian Journal of Experimental Agriculture 48: 387-396. https://doi.org/10.1071/EA07105

DECCW [Department of Environment, Climate Change and Water]. 2010. National recovery plan for white box - yellow box - blakely's red gum grassy woodland and derived native grassland. Retrieved from http://www.environment.gov.au/biodiversity/threatened/recovery-plans/white-box-yellowbox-blakelys-red-gum-grassy-woodland-and-derived-native-grassland-national

Del-Val, E., Crawley, M.J. 2005. Are grazing increaser species better tolerators than decreasers? An experimental assessment of defoliation tolerance in eith British grassland species. Journal of Ecology 93: 1005-1016. https://doi.org/10.1111/j.1365- 
DEWHA [Department of Environment, Water, Heritage and Arts]. 2009. Box gum grassy woodland project: Information booklet. Retrieved from

http://nrmonline.nrm.gov.au/catalog/mql:2397

Dorrough, J., McIntyre, S., Brown, G., Stol, J., Barrett, G., Brown, A. 2012.

Differential responses of plants, reptiles and birds to grazing management, fertilizer and tree clearing. Austral Ecology 37: 569-582. https://doi.org/10.1111/j.1442-9993.2011.02317.x

Dorrough, J., McIntyre, S., Scroggie, M. 2011. Individual plant species responses to phosphorus and livestock grazing. Australian Journal of Botany 59: 670-681.

https://doi.org/10.1071/BT11149

Dorrough, J., Moxham, C. 2005. Eucalypt establishment in agricultural landscapes and implications for landscape-scale restoration. Biological Conservation 123: 55-66.

https://doi.org/10.1016/j.biocon.2004.10.008

Dorrough, J., Moxham, C., Turner, V., Sutter, G. 2006. Soil phosphorus and tree cover modify the effects of livestock grazing on plant species richness in Australian grassy

woodland. Biological Conservation 130: 394-405.

https://doi.org/10.1016/j.biocon.2005.12.032

DSITI [Queensland Department of Science, Information Technology and Innovation].

2017. Land cover change in Queensland 2015-16: A statewide landcover and trees study (SLATS) report. Retrieved from https://publications.qld.gov.au/dataset/4dbd1416-52b7-467a8410-17a70ddf16bf/resource/60a7902d-7a9d-49a7-90b1-a54686fbcef5/download/edocs5799682-v1-slatsreport2015-16.pdf

Duncan, D.H., Dorrough, J.W. 2009. Historical and current land use shape landscape restoration options in the Australian wheat and sheep farming zone. Landscape and Urban Planning 91: 124-132. https://doi.org/10.1016/j.landurbplan.2008.12.007 
Eldridge, D.J., Poore, A.G.B., Ruiz-Colmenero, M., Letnic, M., Soliveres, S. 2016. Ecosystem structure, function, and composition in rangelands are negatively affected by livestock grazing. Ecological Applications 26: 1273-1283. https://doi.org/10.1890/15-1234 Eldridge, D.J., Val, J., James, A.I. 2011. Abiotic effects predominate under prolonged livestock-induced disturbance. Austral Ecology 36: 367-377. https://doi.org/10.1111/j.14429993.2010.02159.x

Ellis, E.C., Klein Goldewijk, K., Siebert, S., Lightman, D., Ramankutty, N. 2010. Anthropogenic transformation of the biomes, 1700 to 2000. Global Ecology and Biogeography 19: 589-606. https://doi.org/10.1111/j.1466-8238.2010.00540.x

Etchebarne, V., Brazeiro, A. 2016. Effects of livestock exclusion in forests of Uruguay: Soil condition and tree regeneration. Forest Ecology and Management 362: 120-129. https://doi.org/10.1016/j.foreco.2015.11.042

Fischer, J., Stott, J., Zerger, A., Warren, G., Sherren, K., Forrester, R.I. 2009. Reversing a tree regeneration crisis in an endangered ecoregion. Proceedings of the National Academy of Sciences 106: 10386-10391. https://doi.org/10.1073/pnas.0900110106

Fischer, J., Zerger, A., Gibbons, P., Stott, J., Law, B.S. 2010. Tree decline and the future of Australian farmland biodiversity. Proceedings of the National Academy of Sciences 107: 19597-19602. https://doi.org/10.1073/pnas.1008476107

Gibbons, P., Briggs, S.V., Ayers, D.A., Doyle, S., Seddon, J., McElhinny, C., Jones, N., Sims, R., Doody, J.S. 2008. Rapidly quantifying reference conditions in modified landscapes. Biological Conservation 141: 2483-2493. https://doi.org/10.1016/j.biocon.2008.07.009 Godfray, H.C.J., Beddington, J.R., Crute, I.R., Haddad, L., Lawrence, D., Muir, J.F., Pretty, J., Robinson, S., Thomas, S.M., Toulmin, C. 2010. Food security: The challenge of feeding 9 billion people. Science 327: 812-818. http://dx.doi.org/10.1126/science.1185383 
Haddad, N.M., Brudvig, L.A., Clobert, J., Davies, K.F., Gonzalez, A., Holt, R.D., Lovejoy, T.E., Sexton, J.O., Austin, M.P., Collins, C.D., Cook, W.M., Damschen, E.I., Ewers, R.M., Foster, B.L., Jenkins, C.N., King, A.J., Laurance, W.F., Levey, D.J., Margules, C.R., Melbourne, B.A., Nicholls, A.O., Orrock, J.L., Song, D-X., Townshend, J.R. 2015. Habitat fragmentation and its lasting impact on Earth's ecosystems. Science Advances $\mathbf{1 .}$ http://dx.doi.org/10.1126/sciadv.1500052

Hautier, Y., Niklaus, P.A., Hector, A. 2009. Competition for light causes plant biodiversity loss after eutrophication. Science 324: 636-638. https://doi.org/10.1126/science.1169640

Hautier, Y., Seabloom, E.W., Borer, E.T., Adler, P.B., Harpole, W.S., Hillebrand, H., Lind, E.M., MacDougall, A.S., Stevens, C.J., Bakker, J.D., Buckley, Y.M., Chu, C., Collins, S.L., Daleo, P., Damschen, E.I., Davies, K.F., Fay, P.A., Firn, J., Gruner, D.S., Jin, V.L., Klein, J.A., Knops, J.M.H., La Pierre, K.J., Li, W., McCulley, R.L., Melbourne, B.A., Moore, J.L., O’Halloran, L.R., Prober, S.M., Risch, A.C., Sankaran, M., Schuetz, M., Hector, A. 2014. Eutrophication weakens stabilizing effects of diversity in natural grasslands. Nature 508: 521. https://doi.org/10.1038/nature13014

Kay, G.M., Mortelliti, A., Tulloch, A., Barton, P., Florance, D., Cunningham, S.A., Lindenmayer, D.B. 2017. Effects of past and present livestock grazing on herpetofauna in a landscape-scale experiment. Conservation Biology 31: 446-458. https://doi.org/10.1111/cobi.12779

Lagendijk, D.D.G., Howison, R.A., Esselink, P., Ubels, R., Smit, C. 2017. Rotation grazing as a conservation management tool: Vegetation changes after six years of application in a salt marsh ecosystem. Agriculture, Ecosystems \& Environment 246: 361-366. https://doi.org/10.1016/j.agee.2017.05.023 
Leonard, S.W.J., Kirkpatrick, J.B. 2004. Effects of grazing management and environmental factors on native grassland and grassy woodland, Northern Midlands, Tasmania. Australian Journal of Botany 52: 529-542. https://doi.org/10.1071/BT03106 Lindenmayer, D.B., Bennett, A.F., Hobbs, R.J. 2010a. How far have we come? Perspectives on ecology, management and conservation of Australia's temperate woodlands. In D.B. Lindenmayer, A.F. Bennett, R.J. Hobbs (Eds.), Temperate woodland conservation and management (pp. 363-374). Melbourne: CSIRO Publishing.

Lindenmayer, D.B., Bennett, A.F., Hobbs, R.J. 2010b. Temperate woodland conservation and management. Melbourne: CSIRO Publishing.

Lindenmayer, D.B., Sato, C. 2018. Hidden collapse is driven by fire and logging in a socioecological forest ecosystem. Proceedings of the National Academy of Sciences 115: 5181-5186. https://doi.org/10.1073/pnas.1721738115

Lindenmayer, D.B., Zammit, C., Attwood, S.J., Burns, E., Shepherd, C.L., Kay, G., Wood, J. 2012. A novel and cost-effective monitoring approach for outcomes in an Australian biodiversity conservation incentive program. PloS One 7: e50872. https://doi.org/10.1371/journal.pone.0050872

Loos, J., Abson, D.J., Chappell, M.J., Hanspach, J., Mikulcak, F., Tichit, M., Fischer, J. 2014. Putting meaning back into "sustainable intensification". Frontiers in Ecology and the Environment 12: 356-361. https://doi.org/10.1890/130157

Manning, A.D., Fischer, J., Lindenmayer, D.B. 2006. Scattered trees are keystone structures: Implications for conservation. Biological Conservation 132: 311-321. https://doi.org/10.1016/j.biocon.2006.04.023

McIntyre, S. 2011. Ecological and anthropomorphic factors permitting low-risk assisted colonization in temperate grassy woodlands. Biological Conservation 144: 1781-1789. https://doi.org/10.1016/j.biocon.2011.03.023 
McIntyre, S. 2012. How agricultural intensification threatens temperate grassy woodlands. In D. Lindenmayer, S. Cunningham, A. Young (Eds.), Land use intensification: Effects on agriculture, biodiversity and ecological processes (pp. 47-53). Melbourne: CSIRO Publishing.

McIntyre, S., Lavorel, S. 2007. A conceptual model of land use effects on the structure and function of herbaceous vegetation. Agriculture, Ecosystems \& Environment 119: 11-21. https://doi.org/10.1016/j.agee.2006.06.013

Natural England 2012. Entry level stewardship: Environmental stewardship handbook. Retrieved from http://publications.naturalengland.org.uk/publication/2798159?category=45001

Onsager, J.A. 2000. Suppression of grasshoppers in the Great Plains through grazing management. Journal of Range Management 53: 592-602. https://doi.org/10.2307/4003152

Pierik, M., Van Ruijven, J., Bezemer, T.M., Geerts, R.H., Berendse, F. 2011. Recovery of plant species richness during long-term fertilization of a species-rich grassland. Ecology 92: 1393-1398. https://doi.org/10.1890/10-0210.1

Prevéy, J.S., Seastedt, T.R. 2014. Seasonality of precipitation interacts with exotic species to alter composition and phenology of a semi-arid grassland. Journal of Ecology 102: 1549-1561. https://doi.org/10.1111/1365-2745.12320

Ranellucci, C.L., Koper, N., Henderson, D.C. 2012. Twice-over rotational grazing and its impacts on grassland songbird abundance and habitat structure. Rangeland Ecology \& Management 65: 109-118. https://doi.org/10.2111/REM-D-11-00053.1

Ravetto Enri, S., Probo, M., Farruggia, A., Lanore, L., Blanchetete, A., Dumont, B. 2017. A biodiversity-friendly rotational grazing system enhancing flower-visiting insect assemblages while maintaining animal and grassland productivity. Agriculture, Ecosystems \& Environment 241: 1-10. https://doi.org/10.1016/j.agee.2017.02.030 
Rumpff, L., Duncan, D.H., Vesk, P.A., Keith, D.A., Wintle, B.A. 2011. State-andtransition modelling for adaptive management of native woodlands. Biological Conservation

144: 1224-1236. https://doi.org/10.1016/j.biocon.2010.10.026

Sato, C.F., Lindenmayer, D.B. 2017. Meeting the global ecosystem collapse challenge.

Conservation Letters 11: e12348. https://doi.org/10.1111/conl.12348

Sato, C.F., Wood, J.T., Stein, J.A., Crane, M., Okada, S., Michael, D.R., Kay, G.M., Florance, D., Seddon, J., Gibbons, P., Lindenmayer, D.B. 2016. Natural tree regeneration in agricultural landscapes: The implications of intensification. Agriculture, Ecosystems \& Environment 230: 98-104. https://doi.org/10.1016/j.agee.2016.05.036

Socher, S.A., Prati, D., Boch, S., Müller, J., Baumbach, H., Gockel, S., Hemp, A., Schöning, I., Wells, K., Buscot, F., Kalko, E.K.V., Linsenmair, K.E., Schulze, E-D., Weisser, W.W., Fischer, M. 2013. Interacting effects of fertilization, mowing and grazing on plant species diversity of 1500 grasslands in Germany differ between regions. Basic and Applied Ecology 14: 126-136. https://doi.org/10.1016/j.baae.2012.12.003

Spooner, P.G., Briggs, S.V. 2008. Woodlands on farms in southern New South Wales: A longer-term assessment of vegetation changes after fencing. Ecological Management \& Restoration 9: 33-41. https://doi.org/10.1111/j.1442-8903.2008.00385.x

Teague, W.R., Dowhower, S.L., Waggoner, J.A. 2004. Drought and grazing patch dynamics under different grazing management. Journal of Arid Environments 58: 97-117. https://doi.org/10.1016/S0140-1963(03)00122-8

TSSC [Threatened Species Scientific Committee]. 2006. Commonwealth listing advice on White Box-Yellow Box-Blakely's Red Gum Grassy Woodland and Derived Native Grassland. Retrieved from http://www.environment.gov.au/biodiversity/threatened/conservation-advices/white-boxyellow-box-blakely\%27s-red-gum-grassy-woodlands-derived-native-grasslands 
van Klink, R., Schrama, M., Nolte, S., Bakker, J.P., WallisDeVries, M.F., Berg, M.P. 2015a. Defoliation and soil compaction jointly drive large-herbivore grazing effects on plants and soil arthropods on clay soil. Ecosystems 18: 671-685. https://doi.org/10.1007/s10021015-9855-Z

van Klink, R., van der Plas, F., van Noordwijk, C.G.E., WallisDeVries, M.F., Olff, H. 2015b. Effects of large herbivores on grassland arthropod diversity. Biological Reviews 90: 347-366. https://doi.org/10.1111/brv.12113

Wassen, M.J., Venterink, H.O., Lapshina, E.D., Tanneberger, F. 2005. Endangered plants persist under phosphorus limitation. Nature 437: 547. https://doi.org/10.1038/nature03950

Whitten, S., Doerr, E., Doerr, V., Langston, A., Wood, A. 2010. Multiple Ecological Communities conservation value metric. Final report for the Australian Government Department of the Environment, Water, Heritage and the Arts. Canberra: CSIRO Sustainable Ecosystems.

Whitten, S., Gorddard, R., Langston, A., Reseson, A. 2009. A review of the Box Gum Grassy Woodlands Environmental Stewardship Project metric. A report for the Australian Government Department of the Environment, Water, Heritage and the Arts. Canberra: CSIRO Sustainable Ecosystems.

Yates, C.J., Hobbs, R.J. 1997. Temperate eucalypt woodlands: A review of their status, processes threatening their persistence and techniques for restoration. Australian Journal of Botany 45: 949-973. https://doi.org/10.1071/BT96091

Zammit, C., Attwood, S., Burns, E. 2010. Using markets for woodland conservation on private lands: Lessons from the policy-research interface. In D.B. Lindenmayer, A.F.

Bennett, R.J. Hobbs (Eds.), Temperate woodland conservation and management (pp.297307). Melbourne: CSIRO Publishing. 


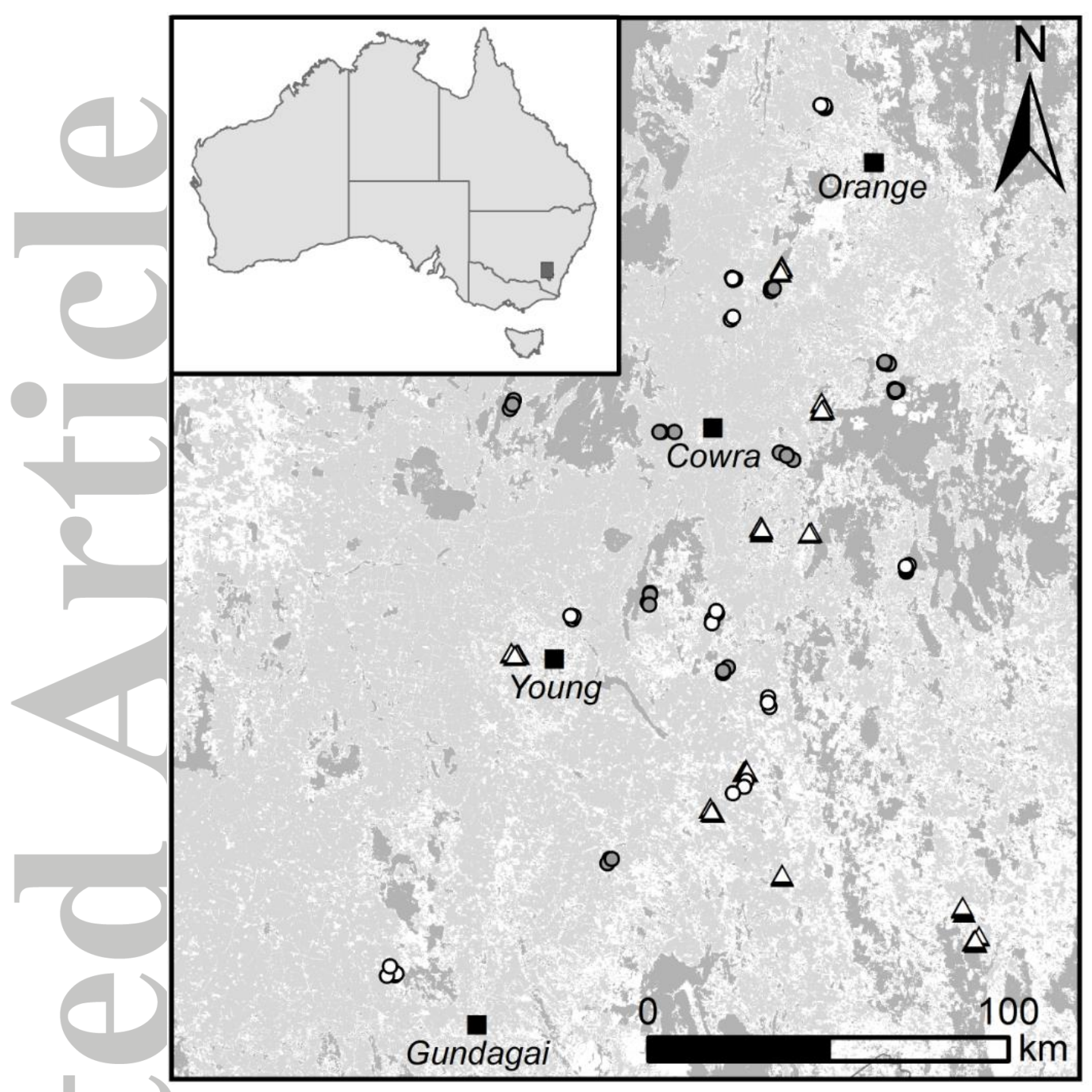

Figure 1. Map of the study region in south-eastern Australia. White circles represent shortconversion rotational sites, grey circles represent long-conversion rotational sites, and white triangles represent continuous grazing sites. Patches of native woody vegetation and modified pastures are delineated by dark grey and light grey shading respectively. 


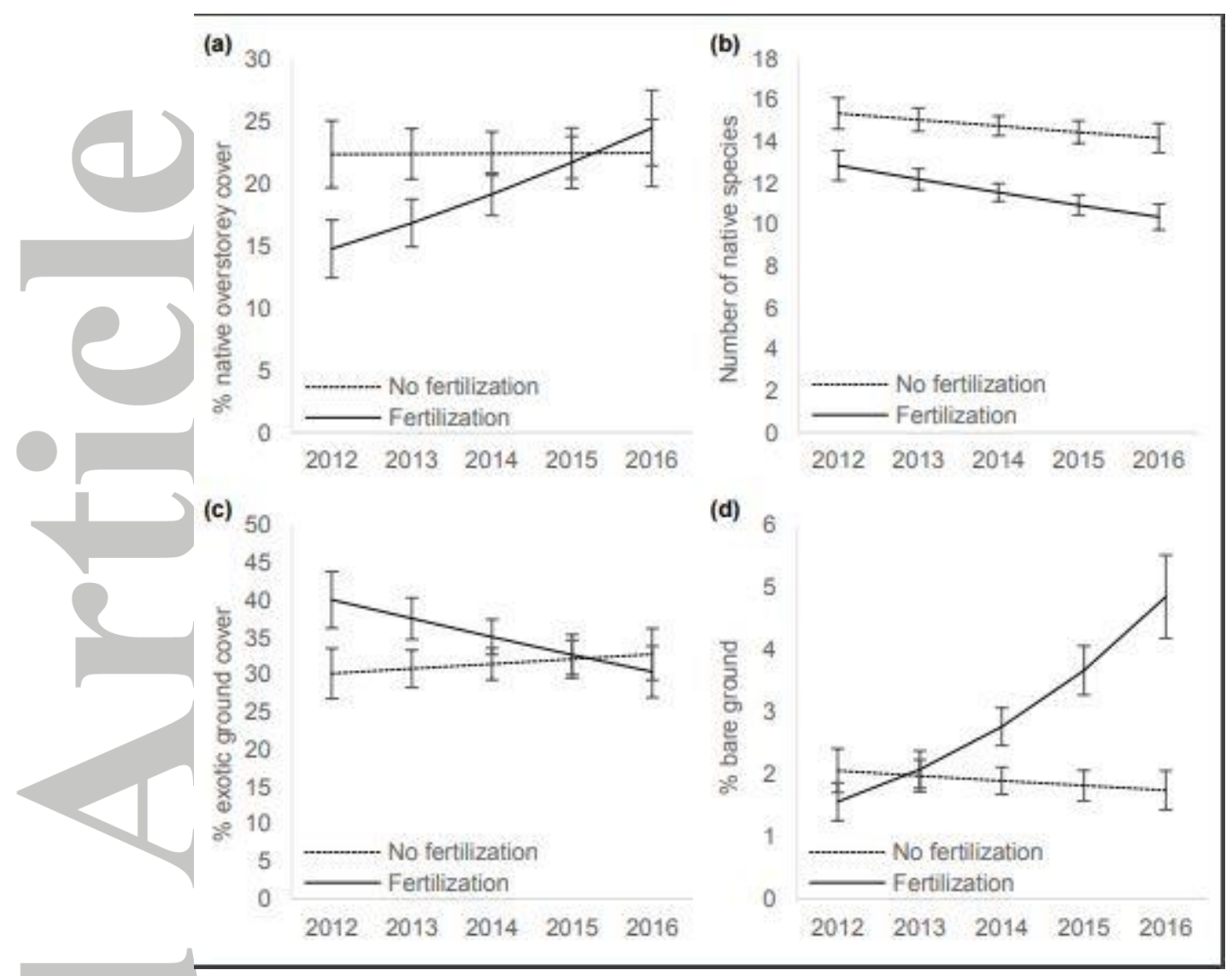

Figure 2. Predicted temporal patterns of (a) native overstorey cover, (b) native plant richness, (c) exotic cover, and (d) bare ground in locations with (dashed lines) and without (solid lines) previous fertilizer application. Error bars represent standard errors of predictions. 


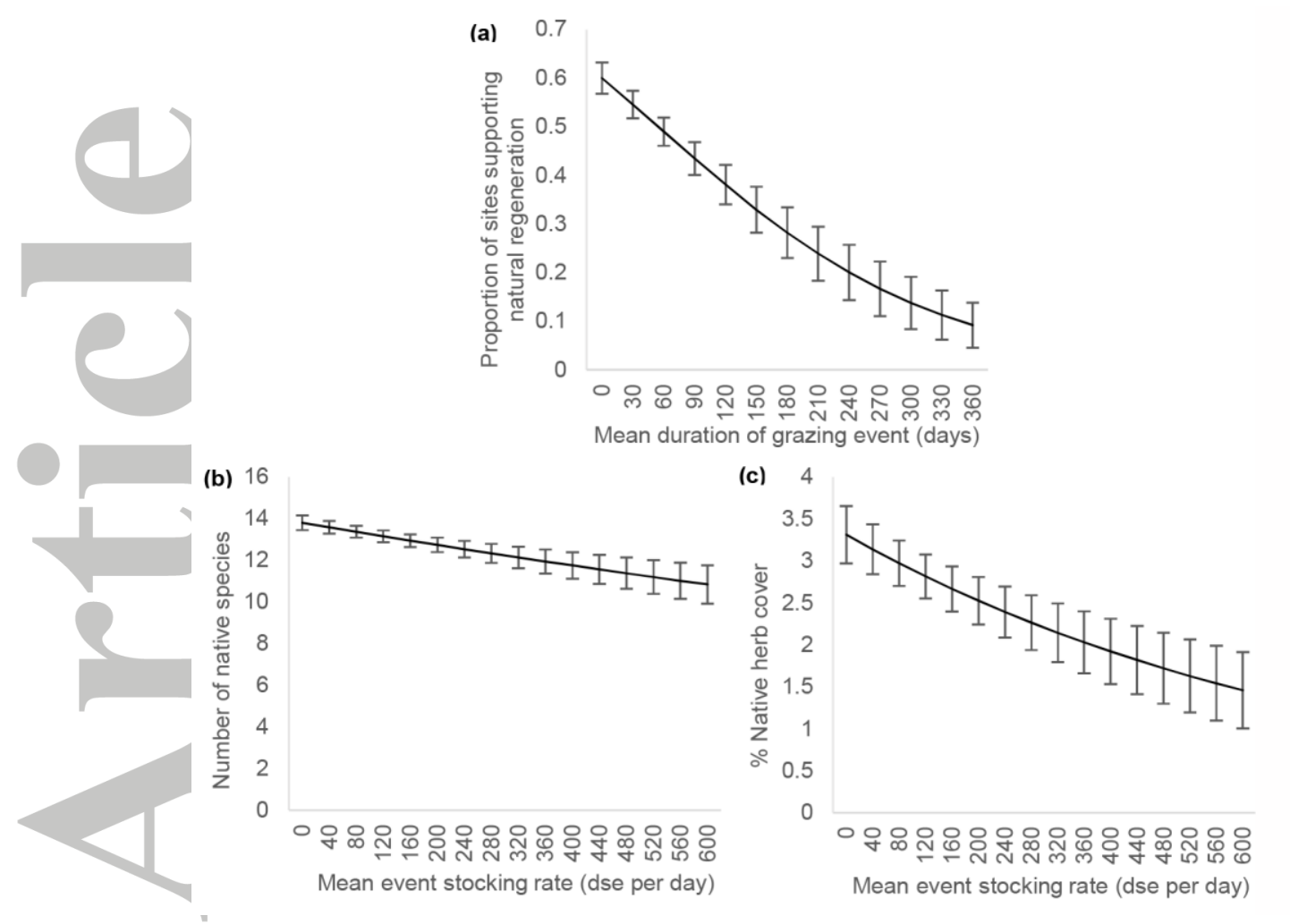

Figure 3. Relationship between (a) grazing duration and proportion of sites predicted to support natural regeneration, (b) stocking rate and predicted native plant species richness at a site, and (c) stocking rate and predicted cover of native herbs at a site. Error bars represent standard errors of predictions. 
Table 1. Grazing management, pasture management and environmental variables included in study.

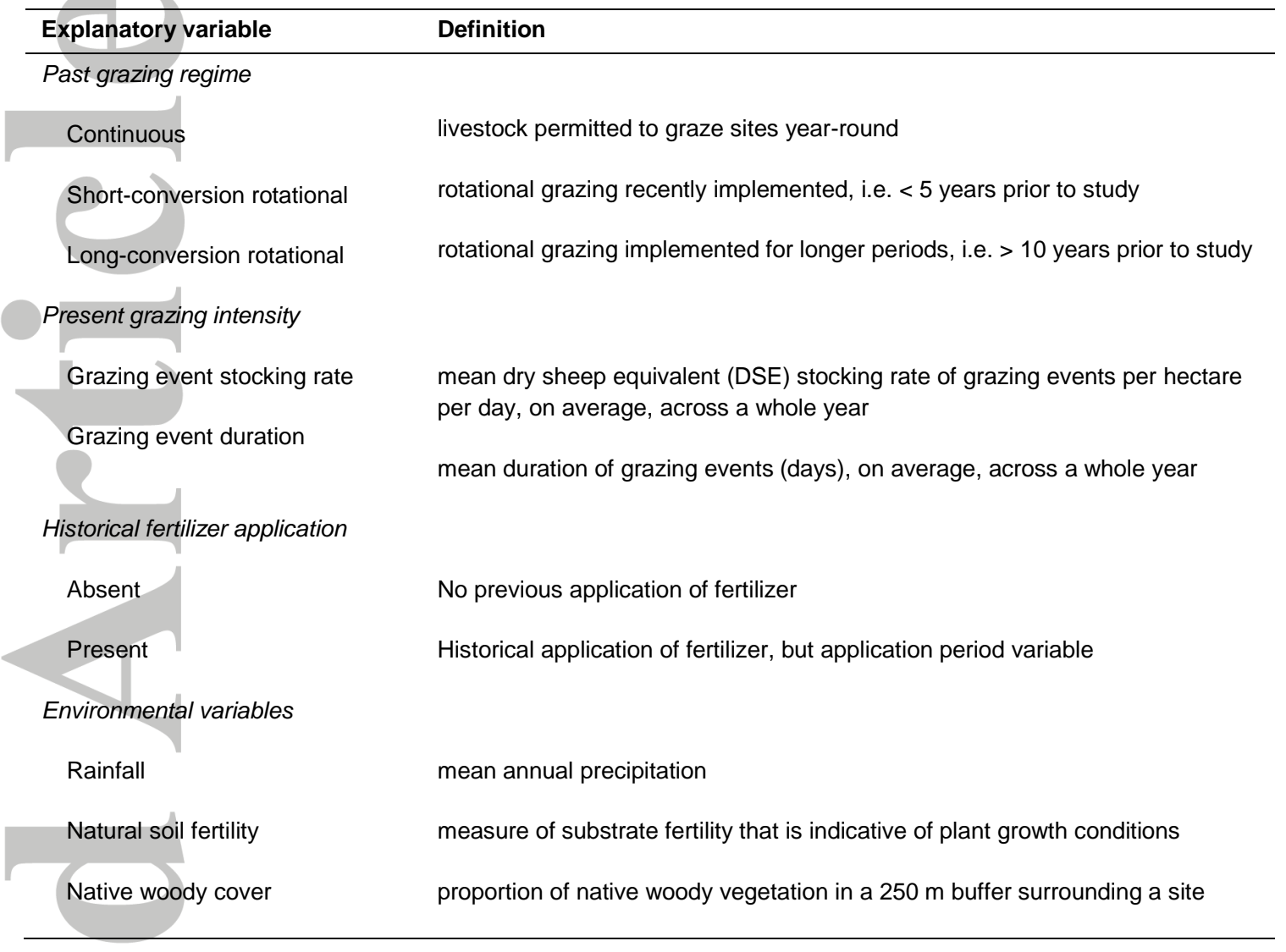


Table 2. Significance of model terms testing the effects of Year, past land management, grazing intensity and environmental covariates on seven woodland condition indicators. Condition indicators modelled include presence of native regeneration (Regen), \% native overstorey cover (\% OS), native plant richness (NPS Richness), \% native herb cover (\% Herb), \% bare ground (\% Bare), exotic plant richness (EPS Richness), and \% exotic ground cover (\% Exotic). Land management variables include past grazing regime (Hist Grazing) and historical fertilization (Hist Fert). Grazing intensity variables include event stocking rate (esr) and duration of grazing event (edg). Environmental covariates include natural soil fertility (Nat Fert), native woody cover (Woody) and mean annual rainfall (Rain).

\begin{tabular}{|c|c|c|c|c|c|c|c|c|}
\hline & & Regen & $\%$ OS & $\begin{array}{c}\text { NPS } \\
\text { Richness }\end{array}$ & $\%$ Herb & $\%$ Bare & $\begin{array}{c}\text { EPS } \\
\text { Richness }\end{array}$ & $\%$ Exotic \\
\hline & $d f$ & Wald & Wald & Wald & Wald & Wald & Wald & Wald \\
\hline Year & 1 & ns & ns & ns & ns & ns & ns & ns \\
\hline Hist Grazing & 2 & ns & ns & ns & ns & ns & ns & ns \\
\hline esr & 1 & ns & ns & $5.45^{\star \star \star}$ & $4.74^{\star \star \star}$ & ns & ns & ns \\
\hline edg & 1 & $5.63^{\star \star \star}$ & ns & ns & ns & ns & ns & ns \\
\hline Hist Fert & 1 & ns & ns & ns & ns & ns & ns & ns \\
\hline Nat Fert & 1 & ns & ns & ns & ns & $8.40^{*}$ & ns & ns \\
\hline Woody & 1 & ns & $9.92^{\star * \star}$ & $5.99^{* * *}$ & ns & ns & ns & $4.26^{\star \star *}$ \\
\hline Rain & 1 & ns & ns & ns & ns & ns & ns & ns \\
\hline \multicolumn{9}{|c|}{ Time * Historical Land Management } \\
\hline Year*Hist Grazing & 2 & ns & ns & ns & ns & ns & ns & ns \\
\hline Year*Hist Fert & 1 & ns & $6.29^{* * *}$ & $3.92^{\star \star *}$ & ns & $7.54^{\star *}$ & ns & $6.43^{\star \star \star}$ \\
\hline
\end{tabular}

$* P<0.05, * * P<0.01, * * * P<0.001, \mathrm{~ns}=$ not significant. 